\title{
Evaluation of RAPD markers for molecular identification of five bamboo genera from Indonesia
}

\author{
Annisa $\bowtie$, Rini Hafzari, Tia Setiawati, Budi Irawan, Joko Kusmoro \\ Universitas Padjadjaran, Faculty of Mathematics and Natural Sciences, Department of Biology, \\ Jl. Raya Bandung-Sumedang Km.21, Jatinangor, Sumedang 45363, West Java, Indonesia, phone: +62 227796412 , \\ e-mail: annisa.annisa4@gmail.com
}

\begin{abstract}
Conservation of bamboos for future exploitation as fuel, fibre and as an ingredient for cosmetics depends on knowledge of its natural genetic variation. The study of molecular genetic diversity in bamboos will provide important information for its conservation. This article reports on the genetic diversity in 25 species representing five genera of bamboos found in Indonesia using Random Amplified Polymorphic DNA (RAPD) molecular markers. Out of 40 primers, 24 primers produced 1107 total bands and $86.21 \%$ of polymorphic bands across the 25 species. Sixteen bands were uniquely found in one species only and their presence or absence helped to define nine bamboo species. RAPD band sizes ranged from 162 to 2247 base pairs. A dendrogram based on the similarity coefficient of Dice divided the bamboo species into three big clusters. In conclusion, RAPD can capture the diversity among five different bamboo genera and has a great potential to be used in the study of genetic diversity in Indonesian bamboos.
\end{abstract}

\section{KeY WORDS}

bamboo, genetics diversity, RAPD, variation

\section{INTRODUCTION}

Bamboo is a non-timber natural resource that has a lot of potential for human use. In this current era, it is used in decorative products, households (such as cooking utensils, toilet paper), building materials, as a fuel and in crafts. Bamboo plantations are useful for conserving soil and water. The bamboo root system produces a cluster of tightly bound shoots that prevent soil erosion (Arsad 2015). Around 1500 species of bamboos are found round the world (Nirala et al. 2016). Indonesia has around 157 species, which represents more than 10\% of global bamboo species (Widjaja and Karsono 2005).
Bogor Botanical Garden (BBG) collects and conserves bamboo species ex situ, and accessions include 11 genera and 43 species of bamboos (Zulkarnaen and Adila 2015). These collections are very important as a base for studies of molecular genetic variation in bamboos in Indonesia.

About 60 species of bamboos can be found in Java, Indonesia, with West Java as one of the largest bamboo producers in Indonesia (Cundaningsih et al. 2015). One district in West Java uses bamboo as an industrial raw material. Karangwangi Village $(\mathrm{K})$ is one of the largest suppliers of black bamboo (Gigantochloa atroviolacea Widjadja) for making angklung, a traditional musical 
instrument (Cundaningsih et al. 2015). However, this black bamboo is still obtained from natural stands and is not yet cultivated. Oktawirani (2013) reported that the demand for black bamboo as an angklung making material can only be met for the next 10 years, considering the limited natural supply of black bamboo. According to An'amillah (2016), in this village, there are also 15 other species of bamboos which are still harvested freely without re-establishing the stands by selective harvesting. This activity will lead ultimately to the extinction of these bamboo species. Therefore, it is very important to have a good knowledge of morphological and molecular genetic variation in these species, as a basis for conservation and sustainable use of bamboo. However, there are only a few studies on molecular genetic variation within and among Indonesian bamboo species.

Knowledge about molecular genetic variation in natural bamboo populations not only helps in developing strategies for its conservation but also improves our understanding of taxonomy and genetics of bamboos (Rao and Hodgkin 2002). Overuse of bamboos in their natural habitats can lead to their extinction. Loh et al. (2000) explained that overexploitation and genetic erosion of bamboos are major reasons for germplasm data collection for the sake of conservation, classification and identification of bamboo. Thus, any research on bamboo genetic diversity is very much needed for conserving bamboo species.

DNA-based molecular markers are often used to determine genetic diversity in plants. According to Das et al. (2008), molecular data can provide useful information to handle any aspects of plant taxonomy and classification. Molecular genetic markers can be useful in taxonomy, to assess the relative level of interspecies and intraspecies genetic diversity (Nayak et al. 2003). Unique alleles, which appear only in one species in a population, may also found in a study using DNA markers (Moges et al. 2016). One DNA-based marker system is Random Amplified Polymorphism DNA (RAPD). This marker uses short oligonucleotides (10 base pairs) as primers, which bind to complementary sequences in the host DNA, followed by amplification and visualisation of amplified DNA. The advantages of using RAPD markers include low cost, fast, no information of plant genome is needed and sensitive in de- termining the genetic relationships between species or individuals (Deshwal et al. 2005).

Several research reports exist on the genetic diversity of bamboos using RAPD markers. Eevera et al. (2008) reported that RAPD markers were useful in the study of genetic variation of 26 species of bamboos in India. Research by Nayak et al. (2003) concluded that RAPD was able to identify bamboo species and genetic relationships between taxa in a cultivation programme in India. RAPD markers were used to determine the relationships between Bambusa species in South Eastern China (Sun et al. 2006) and to test the fidelity of edible bamboo Bambusa clones produced through in vitro propagation (Anand et al. 2013).

In this research, we aim to use RAPD markers to investigate genetic diversity within and between bamboo species belonging to five genera and to identify alleles that are unique for each species.

\section{Material AND Methods}

\section{Plant material}

Plant materials were obtained from in situ collections of Bogor Botanical Garden and also Universitas Padjadjaran Department of Biology bamboo collection from Karawangi. Bamboo species from $\mathrm{K}$ was previously classified based on Dransfield and Widjaja (1995) and Widjaja (2001) (Setiawati et al. 2017). Total of 25 species from five different bamboo genera was used for analysis. Those five genera were: Schizostachyum, Bambusa, Gigantochloa, Dinochloa and Dendrocalamus (Tab. 1). Young leaves were collected and dried using silica gel following the method suggested by Tuner (2015). Young leaf of bamboo was cleaned using alcohol $70 \%$. Plant material was placed into a plastic ziplock bag containing silica gel. The ratio of sample weight and silica gel weight was $1: 10$. Silica gels were replaced when its colour changed. This was continued until the leaves were completely dry.

\section{Extraction, quality and quantity DNA tests}

DNA was extracted from the dried leaf sample using the cetyltrimethylammonium bromide (CTAB) method described by Doyle and Doyle and modified by Vijay and Uttamkumar (2013). Dried leaf sample 
Table 1. Bamboo species used in this research

\begin{tabular}{|c|c|c|c|}
\hline No. & Species name & $\begin{array}{l}\text { Sample } \\
\text { code }\end{array}$ & $\begin{array}{l}\text { Sample } \\
\text { origin }\end{array}$ \\
\hline 1 & $\begin{array}{l}\text { Bambusa vulgaris Scharder ex } \\
\text { Wendland var. vittata A Rivière }\end{array}$ & BV & \multirow{10}{*}{ 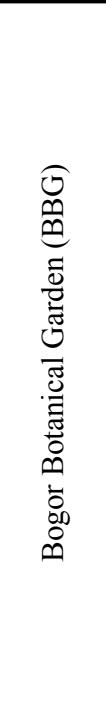 } \\
\hline 2 & Bambusa balcoa Roxb & $\mathrm{BA}$ & \\
\hline 3 & $\begin{array}{l}\text { Gigantochloa atroviolacea } \\
\text { Widjaja }\end{array}$ & GA & \\
\hline 4 & Bambusa glaucophylla Widjaja & BG & \\
\hline 5 & $\begin{array}{l}\text { Dendrocalamus asper (Schultf) } \\
\text { Backer ex Heyne }\end{array}$ & DA & \\
\hline 6 & $\begin{array}{l}\text { Gigantochloa verticillata (Willd.) } \\
\text { Munro forma }\end{array}$ & VE & \\
\hline 7 & Schizostachyum blumei Ness & SL & \\
\hline 8 & $\begin{array}{l}\text { Dinochloa scandens (Blume ex } \\
\text { Nees) Kuntzo }\end{array}$ & DS & \\
\hline 9 & Gigantochloa robusta Kurz & GR & \\
\hline 10 & $\begin{array}{l}\text { Schizostachyum brachycladum } \\
\text { Kurz }\end{array}$ & SB & \\
\hline 11 & Schizostachyum sp. & GE & \multirow{15}{*}{ 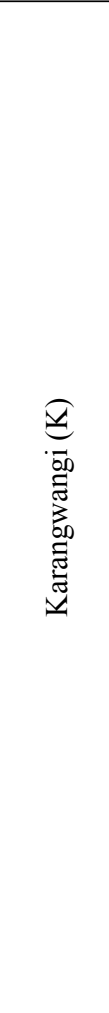 } \\
\hline 12 & Bambusa maculata Widjaja & AS & \\
\hline 13 & $\begin{array}{l}\text { Bambusa blumeana J.A\&J.H } \\
\text { Schultz }\end{array}$ & HG & \\
\hline 14 & $\begin{array}{l}\text { Gigantochloa hassarkaliana } \\
\text { (Kurz.) Backer ex Heyne }\end{array}$ & $\mathrm{AL}$ & \\
\hline 15 & $\begin{array}{l}\text { Dinochloa scandens (Blume ex } \\
\text { Neese) Kuntze }\end{array}$ & $\mathrm{CG}$ & \\
\hline 16 & $\begin{array}{l}\text { B. vulgaris Scharder ex } \\
\text { Wendland var. vittata A Rivière }\end{array}$ & $\mathrm{HK}$ & \\
\hline 17 & G. atroviolacea Widjaja & AD & \\
\hline 18 & G. atroviolacea Widjaja & $\mathrm{AH}$ & \\
\hline 19 & $\begin{array}{l}\text { Gigantochloa pseudoarundinace- } \\
\text { ae (Steud.) Widjaja }\end{array}$ & $\mathrm{AG}$ & \\
\hline 20 & Gigantochloa atter (Hassk.) & AT & \\
\hline 21 & $\begin{array}{l}\text { Gigantochloa apus J.A\&J.H } \\
\text { Schultz. Kurz }\end{array}$ & $\mathrm{AL}$ & \\
\hline 22 & Schizostachyum iraten Widjaja & AY & \\
\hline 23 & G. pseudoarundinaceae Widjaja & $\mathrm{AR}$ & \\
\hline 24 & B. glaucophylla Widjaja & $\mathrm{BC}$ & \\
\hline 25 & $\begin{array}{l}\text { B. vulgaris Schrad. Ex. Wndl. var } \\
\text { vulgaris }\end{array}$ & BI & \\
\hline
\end{tabular}

was placed in a cold mortar and $500 \mu \mathrm{l}$ of extraction buffer (10\% 1M Tris-hydrochloric acid, 10\% $200 \mathrm{mM}$ ethylenediaminetetraacetic acid (EDTA), 40\% 5M sodium chloride, $3 \%$ CTAB, $\beta$-mercaptoethanol and $1 \%$ polyvinylpyrrolidone) was added and the sample was ground. The mixture was then transferred to microtubes and incubated at $65^{\circ} \mathrm{C}$ for $15 \mathrm{~min}$. One hundred microlitres of sodium dodecyl sulphate $(20 \%)$ were added and incubated for $45 \mathrm{~min}$ at $65^{\circ} \mathrm{C}$. Ammonium acetate $(7.5 \mathrm{M} ; 150 \mu \mathrm{l})$ was added and incubated at $4{ }^{\circ} \mathrm{C}$ for $15 \mathrm{~min}$. Chloroform isoamyl alcohol (24:1) was added $1 \times$ mixture volume and centrifuged $(10,000 \mathrm{rpm}$ for $5 \mathrm{~min}$ ). The top supernatant was transferred to a new tube. The DNA present in the supernatant was precipitated in 1 volume of ethanol absolute and washed in ethanol $70 \%$. Pellet was air-dried and suspended in Tris-EDTA buffer and stored at $-20^{\circ} \mathrm{C}$. The quality and quantity DNA were analysed using $0.8 \%$ agarose gel and spectrophotometry by measuring absorbance value on wavelength $\mathrm{A}_{260}$ and $\mathrm{A}_{280}$ to determine the purity and DNA concentration.

\section{Primer screening and RAPD amplification analysis}

This research used 40 RAPD from Operon Technologies Inc. Amplification was conducted following Desai et al. (2015) method. The total polymerase chain reaction (PCR) volume was $25 \mu \mathrm{l}$, which consist of $50 \mathrm{ng} / \mu \mathrm{l}$ DNA template, GoTaq PCR master mix (Promega), $10 \mathrm{uM} / \mu 1$ primer, $1 \mathrm{mM}$ magnesium chloride (Promega) and nuclease-free water. PCR was performed using PCR thermal Cycler (Biorad) with a pre-denaturation at $94^{\circ} \mathrm{C}$ for $5 \mathrm{~min}$, and an amplification process was run for 42 cycles, consisted of denaturation at $94^{\circ} \mathrm{C}$ for $1 \mathrm{~min}$, annealing $38^{\circ} \mathrm{C}$ for $1 \mathrm{~min}$, primer extension at $72^{\circ} \mathrm{C}$ for $1 \mathrm{~min}$ and the final extension for $7 \mathrm{~min}$ at $72^{\circ} \mathrm{C}$. PCR products were analysed with $1.5 \%$ agarose gel in buffer Tris-acetate-EDTA $1 \times \mathrm{x}$ at $70 \mathrm{~V}$ for $70 \mathrm{~min}$. Agarose gel then dyed with GelRed (Biotin) and visualised under UV transilluminator. Primers that gave clear polymorphic bands were chosen for further analysis. DNA amplification with the selected RAPD primers was repeated three times to make sure the reproducibility and consistency of RAPD bands.

\section{Data analysis}

Amplification result was analysed by the total number of bands, band size, polymorphic band numbers and polymorphic information content (PIC) value. Band sizes, band numbers and polymorphic band numbers were determined through electrophoretogram using Gel Analyzer 2010a program. PIC value was measured 
using Avval (2017). Information category of molecular marker based on PIC value was shown in Table 2.

$$
P I C=1-\sum_{1}^{n} f i^{2}
$$

with $\mathrm{fi}^{2}$ as allele frequency $i, i=1,2,3, \ldots$ (Avval, 2017).

Table 2. Category of informative range of molecular markers based on PIC value (Mateescu et al. 2005)

\begin{tabular}{|c|c|}
\hline PIC value & Category \\
\hline$<0.30$ & Non-informative \\
\hline $0.3-0.59$ & Informative \\
\hline$>0.60$ & Very Informative \\
\hline
\end{tabular}

PIC, polymorphic information content.

The cluster analysis was conducted using the XLSTAT 2017 program (trial version), based on the similarity coefficient of Dice (Nayak et al. 2003). The DNA bands were made into matrices 1 and 0,1 if there was a band and 0 otherwise. The principal coordinate analysis (PCoA) was done by using Software PAST (Hammer et al. 2001; Konzen et al. 2017).

\section{Results AND DISCUSSION}

\section{RAPD primer screening and amplification profile analysis RAPD-PCR}

The total primers used in the screening process were 40 RAPD primers. From the 40 primers, only 24 primers were polymorphic bands and analysed further. The example of DNA banding patterns resulted from RAPD-PCR amplification with primer OPA16 is shown in Figure 1. Primer that generated the greatest polymorphism band was OPA 16 (97.30\%). Primer that generated the lowest polymorphic band was OPN 16 (72.41\%). The results were shown in Table 3.

The number of DNA bands per primer and per species varied between 1 and 5 bands and the band size ranged from 162 to $2247 \mathrm{bp}$. The more bands possessed by a locus, the better information about polymorphism the locus provides (Pancoro et al. 2016). Based on the result of RAPD-PCR, the average of monomorphic bands per primer was 6.3 and the average of 39.79 for the polymorphic bands.

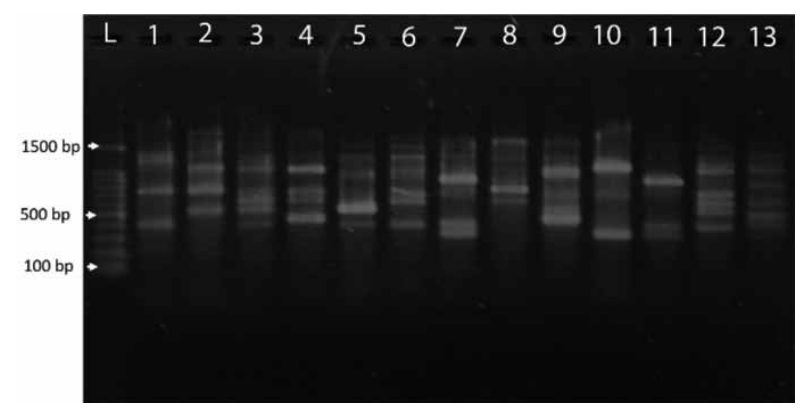

Figure 1. Random Amplified Polymorphic DNA results from primer OPA16. M: Ladder 100 bp; 1: Bambusa vulgaris Schrad; 2: Bambusa balcoa Roxb; 3: Gigantochloa atroviolacea Widjaja; 4: Bambusa glaucophylla Widjaja; 5: Dendrocalamus asper (Schultf) Backer ex Heyne; 6: Gigantochloa verticillata (Willd.) Munro forma; 7: Schizostachyum blumei Ness; 8: Dinochloa scandens (Blume ex Nees) Kuntzo; 9: Gigantochloa robusta Kurz; 10: Schizostachyum brachycladum Kurz; 11: Schizostachyum iraten Widjaja; 12: Gigantochloa atroviolacea Widjaja; 13: Gigantochloa pseudoarundinaceae Widjaja

The level of polymorphism in this study was categorised as high. The difference in the number and polymorphism of the DNA bands produced from each primer illustrates the complexity of the observed plant genomes. In addition, polymorphism is also a picture of amplification obtained from different DNA differences (Syaruddin and Nasution 2012). Polymorphic data can be used for identification in search of the origin of a plant species, knowing relationships between species to the preparation of gene maps. Polymorphic information can also be used as a source that indicates genetic variation, so the data obtained can be used for cross-pollination and selection base (Lelana et al. 2003). This can become a significant support to increase the production of bamboo plants for conservation purposes and sustainable uses.

The value of PIC is determined by the ability of the marker to produce polymorphic bands in the population, depending on the number of bands produced and the frequency of distribution (Chesnokov and Artemyeva 2015). The value of PIC produced in this study ranged from 0.90 to 0.98 . Our result was higher than Konzen et al.'s (2017) RAPD, where PIC ranged from 0.00 to 0.94 . However, our observations were in coherence with the PIC results from Desai et al. (2015).

Based on the informative category of molecular markers (Mateescu et al. 2005), PIC values indicated that the RAPD primers used in this study were very 


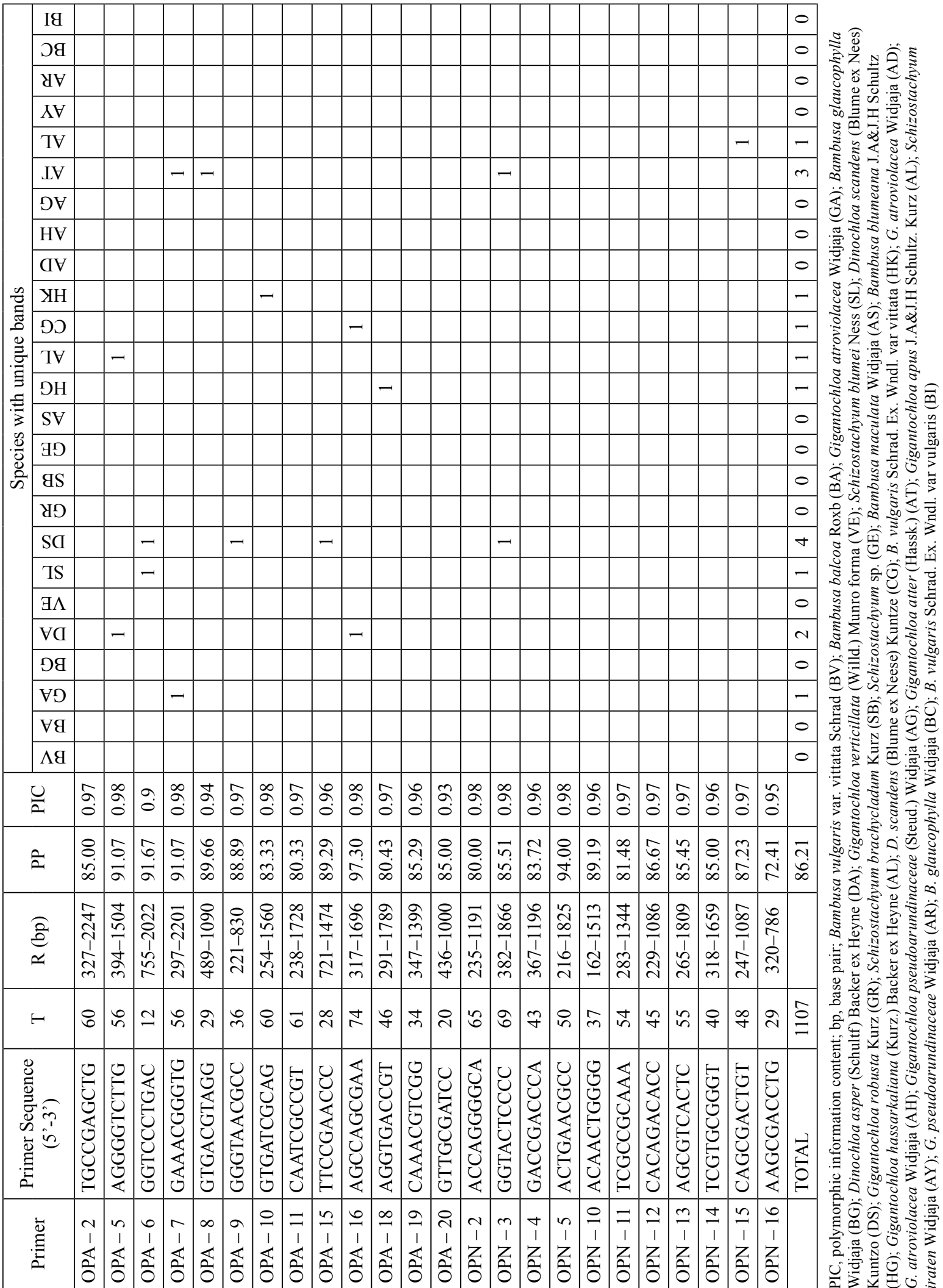


informative and capable of detecting polymorphisms in a population. Thus, these primers can be used to differentiate individuals. If the value of PIC of a primer approaches 1 , then the primer is suitable to be used as a molecular marker (Avval 2017). The RAPD primers used in this study can be recommended for further research of genetic diversity of bamboos in Indonesia.

The high value of polymorphism produced by DNA markers suggests the high level of genetic diversity of species present in the population. Vice versa, the more monomorphic alleles produced by DNA markers, the lower the level of genetic diversity of species in a population. The polymorphic information produced by DNA markers is required in plant breeding program to improve plant quality. This is because DNA markers that produce high polymorphisms can be used to identify the Quantitative Trait Loci of a species used to characterise potentially superior qualities and may be used for selection of elders in plant species to be developed and for conservation (Bi Fu 2015).

\section{Unique bands}

RAPD amplification results in this research were not only showing polymorphic and monomorphic bands but also unique bands. Unique bands are bands that appear only in one species in a population tested by RAPD molecular marker (Thilaga et al. 2017). The example of a unique band produced from the amplification with OPN 3 is shown in Figure 2. This band is only present in sample $D$. scandens (Blume ex Nees). Total 16 unique bands $(1.8 \%$ from the total) were characterised. This percentage number is lower compared with the result of Konzen et al. (2017).

The unique bands have been proven to be informative for the study of genetic populations in the

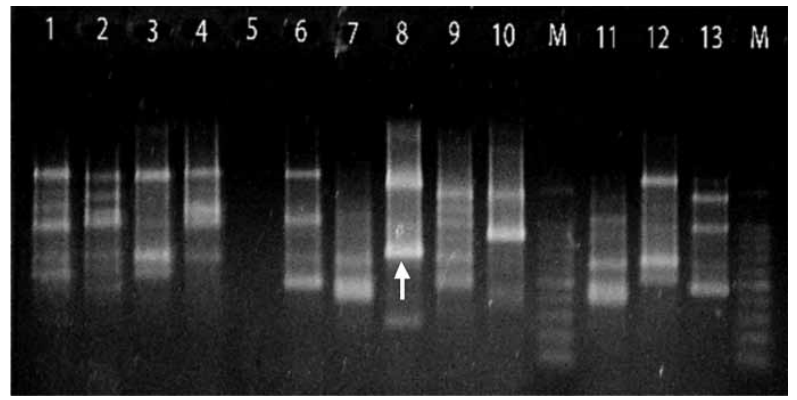

Figure 2. Unique band found in Dinochloa scandens (white arrow) field of molecular ecology and genetic conservation. Unique bands can estimate the rate of mutations in a population and can be used as an indicator of gene flow and to find the theory of modelling the population structure of a species (Szpiech and Rosenberg 2011). The primers that produce unique bands are listed in Table 3 .

The unique bands produced in this study were different for each species and each primer. Based on these data, it can be observed that unique bands can be used to detect specific characteristics for each species of bamboo originating from $\mathrm{K}$ and BBG. According to Patel et al. (2015), the unique bands produced on a species can be designed to be co-dominant molecular markers, so that it can subsequently be used to characterise bamboo species originating from different regions. According to Vijay and Uttamkumar (2013), the unique bands generated on RAPD-PCR can be created to design new Sequence Characterised Amplified Region (SCAR) markers for each species of bamboo that produce a unique band. The SCAR markers can be used as further authentication of bamboo species. Product authentication also plays an important role in conservation efforts because it can monitor the protected species from illegal trade by knowing the origin of the source of raw materials used to produce the product.

\section{Genetic diversity among species}

Based on the level of genetic similarity, bamboos from $\mathrm{K}$ and $\mathrm{BBG}$ were divided into three groups. Group I consisted of four species; Group II consisted of 15 species and Group III consisted of six species (Fig. 3; Tab. 4). The same species of $\mathrm{K}$ and BBG formed one cluster. It can be seen from the dendrogram that B. vulgaris var. vittata from $\mathrm{BBG}$ and $\mathrm{K}$ were clustered together. Other species, D. scandens from BBG and $\mathrm{K}$ were also clustered together. RAPD-PCR was able to distinguish Gigantochloa from BBG (GA, GR and VE) to form a small cluster (monophyletic). Our result was able to separate Schizostachyum blumei and Schizostachyum iraten.

The two-dimensional PCoA plot is also used as another approach to explain the genetic relationship among the 25 bamboos. We observed that varieties of Bambusa (var. vittata and var. vulgaris) were grouped on the same plot, indicating a close relationship. Bamboos were distributed into a separate plot, parallel to dendrogram. This can happen because these species 


\begin{tabular}{|c|c|c|c|c|c|c|c|c|c|c|c|c|c|c|c|c|c|c|c|c|c|c|c|c|c|c|c|c|c|}
\hline 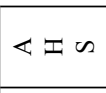 & $\begin{array}{l}\stackrel{0}{\circ} \\
0 \\
0\end{array}$ & $\stackrel{0}{\circ}$ & $\stackrel{\circ}{\circ}$ & $\stackrel{\circ}{0}$ & $\stackrel{\circ}{0}$ & 임 & $\stackrel{0}{0}$ & 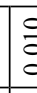 & & & & & $\stackrel{\circ}{\circ}$ & 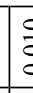 & & & & & ¿̊. & & $\frac{\circ}{2}$ & & & & $\begin{array}{l}\stackrel{0}{\circ} \\
\stackrel{0}{\circ}\end{array}$ & $\stackrel{0}{0}$ & 离 & $\stackrel{8}{\circ}$ & $\stackrel{N}{*}$ \\
\hline$\varangle \leftarrow \Sigma$ & $\stackrel{0}{\circ}$ & $\stackrel{\circ}{\circ}$ & $\stackrel{0}{\circ}$ & $\stackrel{\circ}{\circ}$ & $\stackrel{\circ}{\circ}$ & 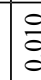 & $\stackrel{\circ}{\circ}$ & $\subsetneq$ & $c$ & & & & & $=$ & & & तิ & & : & $=$ & & & & : & $\stackrel{\circ}{\circ}$ & $\stackrel{0}{0}$ & ¿ & $\stackrel{\infty}{0}$ & 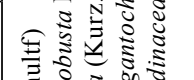 \\
\hline$\ll \Psi \pm$ & $\stackrel{1}{a}$ & $\stackrel{2}{0}$ & $\stackrel{7}{0}$ & ô. & $\stackrel{2}{0}$ & $\Xi$ & $\stackrel{1}{\circ}$ & & 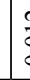 & & है. & & c & & & & : & & $\stackrel{0}{0}$ & & & & & 产 & ã & छ̊. & : & & $\begin{array}{c}0 \\
0 \\
0 \\
0\end{array}$ \\
\hline$\varangle H \Delta$ & 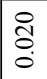 & 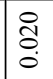 & 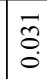 & $\stackrel{1}{0}$ & $\stackrel{\infty}{0}$ & g̊ & $\stackrel{m}{0}$ & & S & & $\begin{array}{l}0 \\
0 \\
0\end{array}$ & 0 & ठิ & c & & & $\begin{array}{l}\circ \\
0 \\
0\end{array}$ & & $\stackrel{0}{0}$ & $n$ & 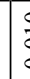 & & & 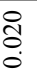 & : & I. & $\stackrel{0}{0}$ & 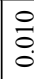 & \\
\hline$\pm \simeq \mathrm{z}$ & $\begin{array}{l}8 \\
0 \\
0\end{array}$ & 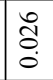 & 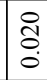 & $\stackrel{1}{0}$ & :̊ & ฮิ & $\stackrel{m}{\circ}$ & a & 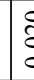 & & है & $\stackrel{0}{0}$ & ֻั & a & & & $\stackrel{0}{0}$ & $\simeq$ & $\stackrel{\circ}{\circ}$ & ¿ & 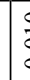 & & & ¿. & 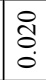 & $\stackrel{0}{0}$ & $\stackrel{0}{0}$ & $\stackrel{\circ}{\circ}$ & 气ै \\
\hline «ـ & $\begin{array}{l}0 \\
0 \\
0 \\
0\end{array}$ & $\begin{array}{l}\circ \\
0 \\
0\end{array}$ & $\stackrel{0}{\circ}$ & $\begin{array}{l}\circ \\
\stackrel{0}{\circ} \\
0\end{array}$ & $\begin{array}{l}\circ \\
\stackrel{0}{\circ} \\
\circ\end{array}$ & $\begin{array}{l}\stackrel{0}{a} \\
\vdots\end{array}$ & 응 & 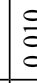 & 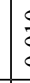 & & $\begin{array}{l}0 \\
0 \\
0\end{array}$ & 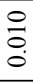 & 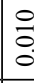 & $\Im$ & & $\begin{array}{l}0 \\
\\
\\
\end{array}$ & $\begin{array}{l}0 \\
\dot{0}\end{array}$ & 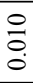 & $\stackrel{\partial}{0}$ & 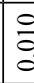 & 9 & & 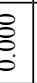 & $\begin{array}{l}\stackrel{0}{0} \\
0 \\
0\end{array}$ & $\begin{array}{l}0 \\
0 \\
0\end{array}$ & $\stackrel{\circ}{\circ}$ & 㝘 & $\frac{2}{0}$ & $=0$. \\
\hline$\varangle 0 n$ & 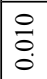 & $\begin{array}{l}0 \\
0 \\
0\end{array}$ & $\stackrel{0}{0}$ & $\stackrel{\circ}{0}$ & : & $\stackrel{\circ}{\circ}$ & $\stackrel{0}{0}$ & c & 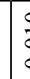 & & : & 으 & $\stackrel{ }{\circ}$ & $\subseteq$ & & & हे & & $\frac{\partial}{0}$ & & 8 & & & $\begin{array}{l}\stackrel{0}{\circ} \\
0 \\
0\end{array}$ & $\stackrel{\circ}{0}$ & 응 & 产 & 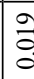 & \\
\hline u & 0 & $\stackrel{n}{0}$ & $\stackrel{n}{0}$ & $\stackrel{2}{0}$ & $\stackrel{n}{0}$ & $a$ & $\stackrel{m}{\circ}$ & $c$ & 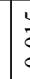 & & है & 0 & 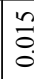 & 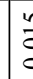 & & E. & $\begin{array}{l}\circ \\
0 \\
0\end{array}$ & & $\stackrel{0}{0}$ & 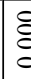 & $\lambda$ & & : & 吕 & $\stackrel{n}{0}$ & $\stackrel{2}{0}$ & $\stackrel{0}{0}$ & & \\
\hline 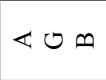 & $\stackrel{\circ}{\circ}$ & $\begin{array}{l}0 \\
\stackrel{0}{0} \\
\stackrel{0}{0}\end{array}$ & $\stackrel{0}{0}$ & $\stackrel{\circ}{\circ}$ & $\stackrel{\circ}{0}$ & $\stackrel{\circ}{\circ}$ & $\stackrel{0}{\circ}$ & $=$ & 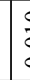 & & : & 의 & $\stackrel{\circ}{\circ}$ & s & & : & $\begin{array}{l}0 \\
\stackrel{0}{0} \\
0\end{array}$ & 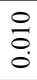 & ¿ & $\cong$ & 9 & & Eे & $\begin{array}{l}\stackrel{0}{0} \\
\vdots \\
0\end{array}$ & $\stackrel{\circ}{\circ}$ & $\stackrel{0}{0}$ & ठ̊. & ฮิ & \\
\hline $0 \omega \Sigma$ & 告 & $\frac{1}{0}$ & 告 & 卓 & בั & a & ב̃ & a & d & & : & $\stackrel{1}{1}$ & $\stackrel{7}{0}$ & à & & to & … & 8 & $\stackrel{0}{\circ}$ & $\simeq$ & 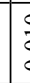 & & 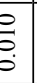 & $\begin{array}{l}\frac{1}{2} \\
\stackrel{0}{0}\end{array}$ & 光 & $\overrightarrow{\tilde{o}}$ & $\stackrel{\circ}{\circ}$ & $\stackrel{0}{0}$ & \\
\hline $\pm 0 \simeq$ & $\stackrel{0}{\circ}$ & $\stackrel{0}{0}$ & 音 & $\stackrel{\circ}{0}$ & $\stackrel{\circ}{0}$ & $\stackrel{\circ}{\circ}$ & $\stackrel{\circ}{\circ}$ & $\subseteq$ & 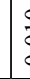 & & : & 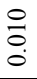 & $\begin{array}{l}\circ \\
\circ\end{array}$ & 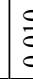 & & E. & ¿̊. & 0 & : & 0 & 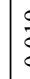 & & b. & $\begin{array}{l}\stackrel{0}{0} \\
\stackrel{0}{0}\end{array}$ & $\stackrel{0}{\circ}$ & $\stackrel{0}{\circ}$ & ठิ & §ิ & \\
\hline 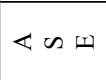 & \begin{tabular}{l} 
\\
\multirow{1}{0}{} \\
0 \\
0
\end{tabular} & $\begin{array}{l}n \\
\tilde{0} \\
0\end{array}$ & : & $\stackrel{\overbrace{}}{0}$ & ¿্. & ฮิ & $\stackrel{m}{\circ}$ & $c$ & $£$ & & $\begin{array}{l}\tilde{z} \\
0 \\
0\end{array}$ & $=$ & 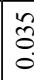 & 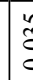 & & : & $\begin{array}{l}\stackrel{0}{0} \\
\stackrel{0}{0}\end{array}$ & & $\stackrel{0}{0}$ & & 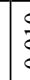 & & : & 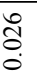 & : & İ & 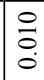 & $\begin{array}{l}\circ \\
0\end{array}$ & \\
\hline$\varangle n \simeq$ & סे & $\begin{array}{l}\vec{n} \\
0\end{array}$ & ठิ & $\frac{7}{0}$ & त्ञ & ฮิ & $\stackrel{m}{\circ}$ & se & 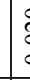 & & है & $\stackrel{2}{0}$ & 离 & $\S$ & & b. & $\begin{array}{l}0 \\
0 \\
0 \\
0\end{array}$ & 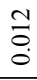 & $\stackrel{0}{\circ}$ & 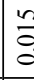 & & & 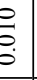 & 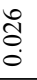 & 客 & $\stackrel{\Xi}{\partial}$ & $\stackrel{\circ}{\circ}$ & 응 & \\
\hline 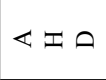 & రి & $\begin{array}{l}\vec{r} \\
0 \\
0\end{array}$ & 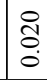 & $\stackrel{\simeq}{\circ}$ & ठ্రి & ฮิ & $\stackrel{m}{\circ}$ & sa & 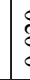 & & 。̃ & 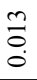 & $\stackrel{\circ}{\circ}$ & a & & $\begin{array}{c}6 \\
: \\
\\
\end{array}$ & $\begin{array}{l}\circ \\
0 \\
0\end{array}$ & & $\stackrel{0}{\circ}$ & & 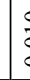 & & E. & 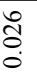 & 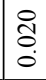 & $\tilde{a}$ & $\begin{array}{l}\circ \\
\stackrel{0}{0} \\
\end{array}$ & $\stackrel{0}{\circ}$ & \\
\hline & $\mid \begin{array}{l}m \\
0 \\
0\end{array}$ & $\stackrel{m}{0}$ & $\mid \begin{array}{l}m \\
0 \\
0\end{array}$ & $\stackrel{\Xi}{0}$ & $\stackrel{m}{0}$ & $\stackrel{\mathrm{a}}{\mathrm{a}}$ & dot & อ & 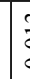 & & to & 8 & $\stackrel{m}{a}$ & 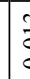 & & है & $\begin{array}{l}\circ \\
\stackrel{0}{0}\end{array}$ & & $\stackrel{\circ}{\circ}$ & & 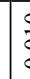 & & : & $\begin{array}{l}m \\
\stackrel{0}{0} \\
0\end{array}$ & $\stackrel{m}{0} \stackrel{0}{\circ}$ & $\frac{1}{0}$ & $\stackrel{0}{\circ}$ & $\stackrel{\circ}{\circ}$ & \\
\hline$\therefore \infty \simeq$ & $\begin{array}{l}\tilde{O} \\
\vdots \\
0\end{array}$ & $\stackrel{1}{0}$ & $\vec{a}$ & $\begin{array}{l}\infty \\
0 \\
0 \\
0\end{array}$ & $\stackrel{T}{0}$ & a & $\cong$ & a & 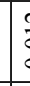 & & 8 & $=$ & $\stackrel{0}{\circ}$ & s & & : & $\begin{array}{l}\circ \\
\stackrel{0}{0}\end{array}$ & 0 & $\stackrel{\circ}{\circ}$ & - & 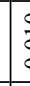 & & : & $\begin{array}{l}\frac{\pi}{0} \\
0 \\
0\end{array}$ & $\stackrel{\Xi}{0}$ & $\overrightarrow{\tilde{O}}$. & $\stackrel{\circ}{\circ}$ & $\begin{array}{l}\circ \\
0\end{array}$ & \\
\hline $0 \simeq 0$ & $\begin{array}{l} \\
\delta \\
\delta \\
0\end{array}$ & 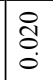 & 官 & 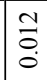 & $\overline{\tilde{o}}$ & $\stackrel{8}{\circ}$ & $\stackrel{m}{\circ}$ & a & 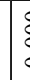 & & है & $\cong$ & d. & 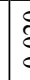 & & D. & $\begin{array}{l}\circ \\
\stackrel{0}{0}\end{array}$ & 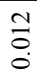 & $\stackrel{\circ}{\circ}$ & 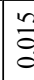 & 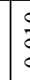 & & : & 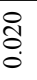 & $\overrightarrow{\tilde{\rho}}$ & $\stackrel{\tilde{a}}{0}$ & $\stackrel{\circ}{\circ}$ & c & \\
\hline$\backsim u$ & $\stackrel{n}{0}$ & $\stackrel{n}{0}$ & 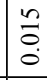 & $\stackrel{I}{\circ}$ & $\begin{array}{l}n \\
0 \\
0 \\
0\end{array}$ & $\stackrel{n}{a}$ & $\stackrel{m}{0}$ & 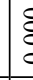 & 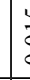 & & $\begin{array}{l}a \\
:\end{array}$ & $\stackrel{m}{=}$ & $\stackrel{n}{\circ}$ & $y$ & & $\overbrace{0}^{0}$ & $\begin{array}{l}\circ \\
\stackrel{0}{0}\end{array}$ & 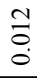 & $\stackrel{\circ}{\circ}$ & & 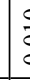 & & : & $\begin{array}{l}n \\
0 \\
0 \\
0\end{array}$ & $\stackrel{n}{0}$ & ã. & $\stackrel{0}{\circ}$ & co & \\
\hline$\therefore \infty$ & 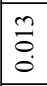 & $\stackrel{m}{0}$ & $\stackrel{m}{0}$ & 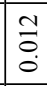 & $\stackrel{m}{0}$ & $\stackrel{m}{a}$ & @ & & 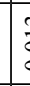 & & $\frac{1}{6}$ & & $\stackrel{m}{=}$ & & & : & $\begin{array}{l}\stackrel{0}{0} \\
0 \\
0\end{array}$ & & $\stackrel{\circ}{\circ}$ & & & & E. & $\begin{array}{l}\frac{m}{0} \\
0 \\
0\end{array}$ & $\stackrel{m}{0} 0$ & $\frac{1}{0}$ & $\stackrel{\circ}{\circ}$ & $\stackrel{0}{\circ}$ & \\
\hline & $\begin{array}{l}\text { त्रे } \\
\text { ¿. }\end{array}$ & 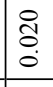 & $\begin{array}{l}\text { ¿े } \\
\stackrel{0}{0}\end{array}$ & $\begin{array}{l}\text { oี } \\
\stackrel{0}{0}\end{array}$ & $\stackrel{\bar{o}}{\circ}$ & ఏ & $\stackrel{m}{0}$ & $c$ & 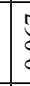 & & है & & సి & & & D. & $\begin{array}{l}\circ \\
0 \\
0\end{array}$ & & $\stackrel{0}{\circ}$ & & & & : & 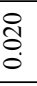 & $\overrightarrow{\tilde{o}_{0}}$ & a & $\stackrel{\circ}{\circ}$ & 0 & \\
\hline$\ll n$ & $\begin{array}{l} \\
\delta \\
0 \\
0\end{array}$ & 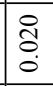 & $\overrightarrow{\tilde{o}}$ & $\stackrel{T}{T}$ & $\stackrel{8}{\circ}$ & סू & $\stackrel{m}{8}$ & 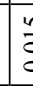 & 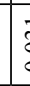 & & ह. & $\underline{2}$ & ฉิ & $\varepsilon$ & & D. & $\begin{array}{l}\stackrel{\circ}{\circ} \\
0 \\
0\end{array}$ & & $\stackrel{\circ}{\circ}$ & & & & 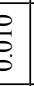 & 范 & $\begin{array}{l}\infty \\
\\
0 \\
0 \\
0\end{array}$ & 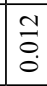 & $\stackrel{\circ}{\circ}$ & 0 & \\
\hline ניـ ט ט & $\stackrel{1}{0}$ & $\stackrel{1}{0}$ & İ & 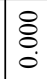 & $\stackrel{I}{0}$ & 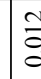 & $\stackrel{1}{0}$ & ภ & 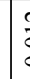 & & & $\simeq$ & $\cong$ & & & E. & $\begin{array}{l}\circ \\
\stackrel{0}{0}\end{array}$ & 6 & $\stackrel{\circ}{0}$ & & & & D. & 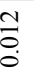 & Õ & $\overrightarrow{\tilde{\delta}}$ & $\stackrel{0}{\circ}$ & & \\
\hline 4 & ¿̊. & 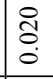 & $\stackrel{\text { ¿ }}{\circ}$ & $\begin{array}{l}\cong \\
\vdots \\
0\end{array}$ & $\bar{c}$ & $\stackrel{0}{0}$ & $\stackrel{m}{0}$ & & 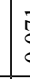 & & & & ๙ิ & & & : & $\begin{array}{l}\circ \\
\stackrel{0}{0}\end{array}$ & & $\stackrel{\circ}{\circ}$ & & & & ? & ڤ్రి & $\overrightarrow{\tilde{o}}$ & $\stackrel{2}{0}$ & $\stackrel{0}{\circ}$ & & \\
\hline$\infty \varangle\lrcorner$ & $\begin{array}{l} \\
\text { ô. } \\
0 \\
0\end{array}$ & $\begin{array}{l}8 \\
\vdots \\
0\end{array}$ & $\begin{array}{l}\text { ठิ } \\
\text { ¿े }\end{array}$ & $\begin{array}{l}\text { I. } \\
\vdots \\
0\end{array}$ & 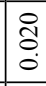 & 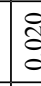 & $\stackrel{m}{0}$ & c & $\delta$ & & है. & 0 & $\sqrt{n}$ & & & $\hat{\circ}$ & $\begin{array}{l}\circ \\
0 \\
0\end{array}$ & & $\begin{array}{l}\circ \\
\stackrel{0}{0} \\
\end{array}$ & & & & b. & 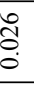 & 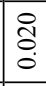 & $\frac{1}{0}$ & $\stackrel{\circ}{\circ}$ & & \\
\hline$>-1$ & $\begin{array}{l}8 \\
\vdots \\
0\end{array}$ & $\begin{array}{l}{ }_{0} \\
\stackrel{1}{1} \\
0\end{array}$ & 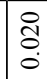 & 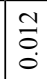 & 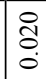 & ฮิ & $\stackrel{m}{\circ}$ & & 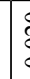 & & E. & & 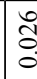 & & & 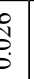 & $\begin{array}{l}\circ \\
\vdots \\
0 \\
0\end{array}$ & & $\stackrel{\circ}{\circ}$ & & & & & 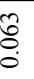 & : & $\frac{1}{0}$ & $\stackrel{0}{\circ}$ & & \\
\hline & 窇 & 㐫 & 悹 & 苂 & $\frac{n}{\Delta}$ & $\begin{array}{l}z \\
y\end{array}$ & $\ddot{w}$ & & ( & & 兹 & 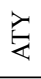 & & & & Inth & 节 & & 위 & & & & $\frac{4}{4}$ & & 晏 & 焉 & $\sum$ & & \\
\hline
\end{tabular}




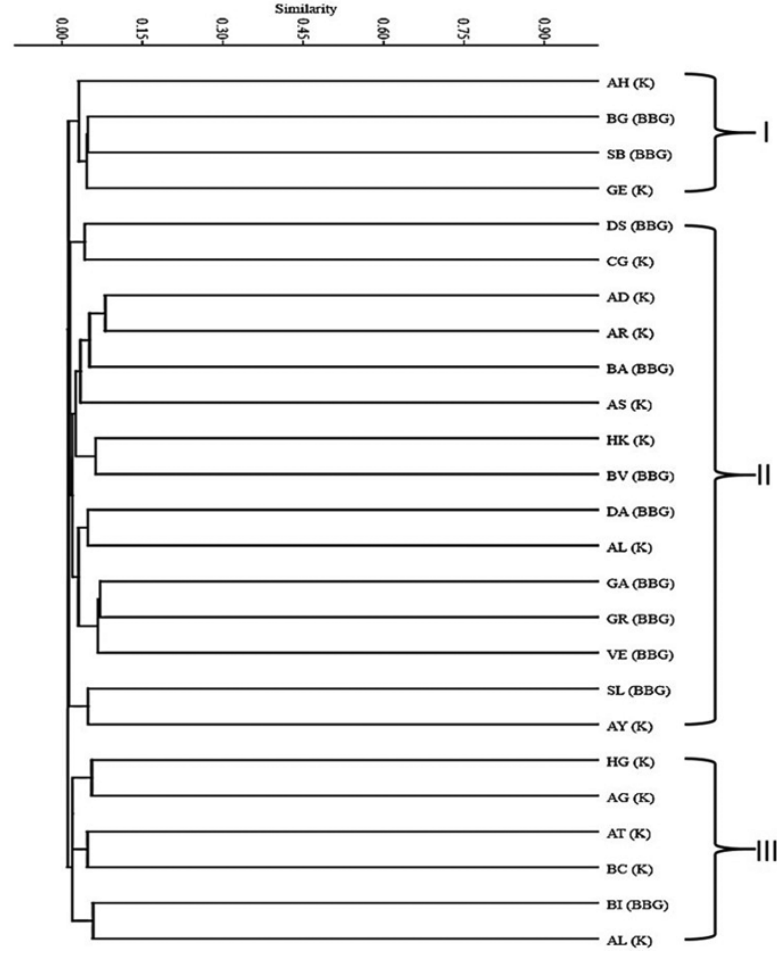

Figure 3. Dendrogram of 25 species of bamboo based on Dice similarity coefficient

Note: Bambusa vulgaris var. vittata Schrad (BV); Bambusa balcoa Roxb (BA); Gigantochloa atroviolacea Widjaja (GA); Bambusa glaucophylla Widjaja (BG); Dendrocalamus asper (Schultf) Backer ex Heyne (DA); Gigantochloa verticillata (Willd.) Munro forma (VE); Schizostachyum blumei Ness (SL); Dinochloa scandens (Blume ex Nees) Kuntzo (DS); Gigantochloa robusta Kurz (GR); Schizostachyum brachycladum Kurz (SB); Schizostachyum sp. (GE); Bambusa maculata Widjaja (AS); Bambusa blumeana J.A\&J.H Schultz (HG); Gigantochloa hassarkaliana (Kurz.) Backer ex Heyne (AL); D. scandens (Blume ex Neese) Kuntze (CG); B. vulgaris Schrad. Ex. Wndl. var vittata (HK); Gigantochloa atroviolacea Widjaja (AD); $G$. atroviolacea Widjaja (AH); Gigantochloa pseudoarundinaceae (Steud.) Widjaja (AG); Gigantochloa atter (Hassk.) (AT); Gigantochloa apus J.A\&J.H Schultz. Kurz (AL); Schizostachyum iraten Widjaja (AY); G. pseudoarundinaceae Widjaja (AR); B. glaucophylla Widjaja (BC); B. vulgaris Schrad. Ex. Wndl. var vulgaris (BI).

produced almost identical DNA bands and DNA patterns in most of the primers used. This showed that RAPD primers can be used to identify species from the field and compared it with the ones from the in situ collection. According to Jena and Das (2006), the banding pattern and the number of alleles generated on RAPD amplification will affect the grouping of species based on genetic similarities.

We noticed that not all Bambusa species were clustered together in both analyses. This might be possible because there are variations in the number of different chromosomes from the genus Bambusa. Sharma et al. (2008) reported that the polyploidy levels in the Bambusa species are high, and Yeasmin (2015) suggested that there are variations in the number of chromosomes in some species of Bambusa. Report from Goh et al. (2010) also found that some Bambusa species were clustered with Dendrocalamus and Gigantochloa based on nuclear DNA topology.

Based on the number of chromosomes, six species of bamboos in Group III have the same number of chromosomes, that is, $2 n=6 x=72$ (hexaploid) (Dransfield and Widjaja 1995; Köhl 2016). In addition, in this study, the bands obtained from primers used for the six bamboo species in Group III yielded a similar pattern of DNA bands and nearly the same number of bands. According to Jena and Das (2006), the pattern of DNA bands resulting from RAPD amplification is influenced by the number of chromosomes of the species. Additionally, clustering of several species in the same group can be caused by the number of chromosomes belonging to the same species. Pirre et al. (2011) and Das et al. (2015) suggested that variations in the number of chromosomes influence the population structure of a species.

In this research, we also found that the same species that were collected from a different latitude and longitude were grouped into cluster II; however, they were located in different subclusters. Schoettle et al. (2012) found similar results on the Pinus aristata Engelm from Colorado and New Mexico diversity based on isozyme diversity.

Based on Bamboo Phylogeny Group (2012), Bambuseae tribe is divided into 11 subtribes. The results of this study grouped bamboo samples tested into two subtribes, namely, Bambusinae and Melocanninae. The subtribe Bambusinae consists of the genus Bambusa, Gigantochloa and Dinochloa. Subtribe Melocanninae consists of the genus Schizostachyum. The results of this study are in accordance with the grouping of tribe Bambuseae, which is divided into two subtribes and contains the same genus. But in Groups I and II, there were different genera joined together into one group that was the Schizostachyum genus. Our result is parallel with Triplett et al. (2014); the genus Schizostachyum is still cannot be separated from other genus. This may be the case because Bambusae is allopolyploid which 


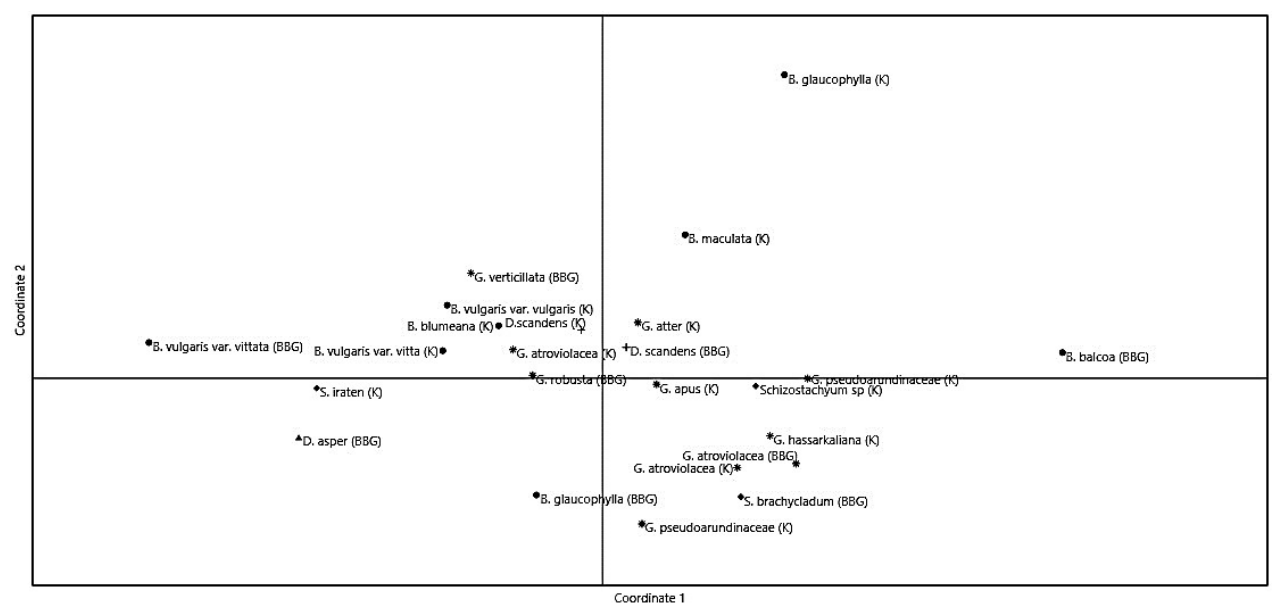

Figure 4. Principal coordinate analysis (PCoA) of 25 bamboo taxa based on Random Amplified Polymorphic DNA. • for the genus Bambusa; $\boldsymbol{\Delta}$ for the genus Dendrocalamus; + for the genus Dinochloa; * for the genus Gigantochloa; $\checkmark$ for genus Schizostachyum

shares $\mathrm{C}$ and $\mathrm{D}$ genome. The RAPD primers used were not able to separate the Schizostachyum genus clustered into one appropriate subtribe. This is because these RAPD primers are not designed to differentiate both genomes. Reflinur and Lestari (2015) suggested that the more DNA markers used, the more likely it is to obtain a complete and accurate genetic map.

The coefficient of Dice similarity in bamboo species produced in this study ranged from 0.000 to 0.081. According to Haiti (2003), the smaller the value of the coefficient of genetic similarity, the farther the kinship relationship is. On the contrary, the greater the value of the coefficient of genetic similarity, the closer the kinship relationship is. There are several factors affecting the level of genetic diversity including gene flow, inbreeding, mutations caused by deletion or insertion (Nadeem et al. 2017).

The closest kinship occurs in the species G. atroviolacea Widjaja (AD) and G. pseudoarundinaceae Widjaja (AR) with a value of 0.081 equality coefficient (Tab. 4). The genetic variation found in bamboo species may be caused by a number of factors, including the biological reproductive system, distance, geography and ecology (Pratiwi 2012).

This study showed that the data generated using RAPD molecular markers can be used to help determine the genetic diversity of bamboos found in $\mathrm{BBG}$ and $\mathrm{K}$. The results of this study can be useful for plant improvement and detection of genetic variation among bamboo species. Information on genetic diversity is needed to support conservation activities. For conservation activities, the magnitude of genetic diversity reflects the genetic resources needed for shortterm ecological adaptation and long-term evolution (Afza 2016).

\section{Acknowledgements}

The authors would like to express special thanks to the Indonesia Ministry of Research, Technology and Higher Education for funding this research (718/ UN6.3.1/PL/2017). The authors also thank Bogor Botanical Garden for providing with sample materials. The authors also like to thank Novio Ananti Yusril for assisting in the process of taking the sample material and Prof. Wallace A. Cowling from The University of Western Australian and Dr. Annaliese S Mason from Justus Liebig University for the discussions.

\section{References}

Afza, H. 2016. Role of conservation and characterization of genetic resources of red rice in plant breeding (in Indonesian). Jurnal Litbang Pertanian, 35 (3), 143-153.

Anand, M., Brar, J., Sood, A. 2013. In vitro propagation of an edible bamboo bambusa bamboos and assessment of clonal fidelity through molecular 
markers. Journal of Medical and Bioengineering, 2, 257-261.

An'amillah, A. 2016. Pengetahuan Lokal Masyarakat Desa Karangwangi Kecamatan Cidaun Kabupaten Cianjur Mengenai Keanekaragaman Jenis, Pemanfaatan, dan Pengelolaan Bambu. (in Indonesian). Undergraduate Thesis. Biologi Fakultas MIPA Universitas Padjadjaran. Unpublished.

Arsad, E. 2015. The technology process and used of bamboo (in Bahasa Indonesian). Journal Riset Industri Hasil Hutan, 7, 45-52.

Avval, E.S. 2017. Assessing polymorphism information content (pic) using ssr molecular markers on local species of Citrullus colocynthis. Case study: Iran. Sistan-Balounchestan Province. Journal of Molecular Biology Research, 7, 42-49

Bamboo Phylogeny Group. 2012. An updated tribal and subtribal classification of the bamboos (Poaceae: Bambusoideae). The Journal of the American Bamboo Society, 24, 1-10.

$\mathrm{Bi} \mathrm{Fu}, \mathrm{Y}$. 2015. Understanding crop genetic diversity under modern plant breeding. Theoretical and Applied Genetics, 128, 1231-2142.

Chesnokov, V.Yu, Artemyeva, A.M. 2015. Evaluation of the measure of polymorphism information of genetic diversity. Agricultural Biology, 50, 571-578.

Cundaningsih, N., Saputri, R.S., Arosyani, E., Amalia, A., Irawan, B. 2015. Ecological study of black bamboo as angklung raw materials in West Java (in Bahasa Indonesian). Prosiding Seminar Nasional Masyarakat Biodiversitas Indonesia, 1 (7), 1600-1604.

Das, M., Bhattacharya, S., Singh, P., Filgueiras, T.S., Pal, A. 2008. Bamboo taxonomy and diversity in the era of molecular markers. Advances in Botanical Research, 47, 2-45.

Das, B.A., Das, A., Pradhan, C., Naskar, S.M. 2015. Genotypic variations of ten Indian cultivars of colocasia esculenta var. Antiquorom schott. Evident by chromosomal and RAPD markers. Caryologia: International Journal of Cytology, Cytosystematics and Cytogenetics, 68 (1), 44-54.

Desai, P. et al. 2015. Comparative assessment of genetic diversity among Indian bamboo genotypes using RAPD and ISSR markers. Molecular Biology Report, 42, 1265-1273.
Deshwal, S.P.R., Singh, R., Malik, K., Randhawa, G.J. 2005. Assessment of genetic diversity and genetic relationships among 29 population of Azadirachta indica A.Juss. using RAPD markers. Genetic Resources and Crop Evolution, 52, 285-292.

Dransfield, S., Widjaja, E.A. 1995. Plant resources of South-East Asia No.7. Bamboos. Prosea Foundation. Bogor. Indonesia.

Eevera, T., Rajendran, K., Saradha, S., Lashmi, A. 2008. Analysis of genetic variation in selected bamboo species using RAPD. Tree and Forestry and Biotechnology, 2, 54-56.

Goh, W.L., Chandran, S., Lin, R.S., Xia, N.H., Wong, K.M. 2010. Phylogenetic relationships among Southeast Asian climbing bamboos (Poaceae: Bambusoideae) and the Bambusa complex. Biochemical Systematics and Ecology, 38, 764-773.

Haiti, S. 2003. Estimation of genetic distance and genetic relationship of pineapple based on isozyme analysis. Journal Hortikultura, 13, 87-94.

Hammer, Ø., Harper, D.A.T., Ryan, P.D. 2001. PAST: Paleontological Statistics Software Package for Education and Data Analysis. Palaeontologia Electronica, 4.

Jena, S.N., Das, B.A. 2006. Inter-population variation of chromosome and RAPD markers of Suaeda nudiflora (Willd.) Moq. a mangrove species in India. African Journal of Agricultural Research, 1 (4), 137-142.

Köhl, M. 2016. Silviculture of South Asian Priority Bamboos. [eBook]. Springer

Lelana, E., Sutarno, N., Etikawati, N. 2003. Identification of polymorphism on ND-5 mitochondrial DNA fragment of Benggala and Madura cattle with PCRRFLP technique (in Indonesian). Biodiversitas, 4, $1-6$.

Konzen, E., Peron, R., Ito, M., Brondani, G., Tsai, S. 2017. Molecular identification of bamboo genera and species based on RAPD-RFLP markers. Silva Fennica, 51, 1-16.

Loh, P.J., Kiew, R., Set, O., Gan, L.H., Gan ,Y.Y. 2000. A Study of genetic variation and relationships within the Bamboo subtribe bambusinae using Amplified Fragment Length Polymorphism. Annals of Botany, 85, 607-610.

Matesscu, G.R. et al. 2005. Analysis of allele fidelity polymorphic information content, and density of 
microsatellites in a genome-wide screening for hip dysplasia in a crossbreed pedigree. Journal of Heredity, 96, 847-853.

Moges, D.A. et al. 2016. Development of microsatellite markers and analysis of genetic diversity and population structure of Colletotrichum gloeosporioides from Ethiopia. Plos One, 11, 1-18.

Nadeem M.A. et al. 2017. DNA molecular markers in plant breeding: current status and recent advancements in genomic selection and genome editing. Biotechnology and Biotechnological Equipment, 32 (2), 261-285.

Nayak, S., Rout, G.R., Das, P. 2003. Evaluation of the genetic variability in bamboo using RAPD markers. Plant, Soil and Environment, 49, 24-28.

Nirala, P.D., Jain, S.C., Kumari, P. 2016. Distribution of different bamboo species in different areas of North Chota Nagpur division of Jharkhand. Bioscience Discovery, 7, 21-24.

Thilaga, S., Rahul, N. R., Rajesh, K.M., Ganesh, D. 2017. RAPD markers for screening shoot gall maker (Betousa stylophora Swinhoe) tolerant genotypes of amla (Phyllanthus emblica L.). Journal of Genetic Engineering and Biotechnology, 15, 323-330.

Oktawirani, P. 2013. Perencanaan Interpretasi Berbasis Konservasi Bambu Sebagai Bahan Baku Angklung di Saung Angklung Udjo (in Indonesian). Thesis. Institut Pertanian Bogor.

Pancoro, A., Septiyani, T.A., Indriyani, N.L.P., Santoso, P.J. 2016. Analysis of F1 progenies of intra and inter species crossing of durian (Durio sp.) using microsatellite markers (in Indonesian). Jurnal Hortikultura, 26, 171-180.

Patel, H.K., Fougat, R.S., Kumar, S., Mistry, J.G., Kumar, M. 2015. Detection of genetic variation in Ocimum species using RAPD and ISSR markers. 3 Biotech, 5 (5), 697-707.

Pierre, M.O.P., Sousa, M.S., Davide, L.C., Machado, A.M., Viccini, F.L. 2011. Karyotype analysis, DNA content and molecular screening in Lippia alba (Verbenaceae). Annals of the Brazillian Academy of Sciences, 83 (3), 993-1005.

Pratiwi, P. 2012. Analisis Variasi Genetik Beberapa Populasi Globba leucantha Miq. Di Sumatra Barat Dengan Random Amplified Polymorphic DNA (RAPD) (in Indonesian). Thesis. Universitas Andalas.
Rao, R.V., Hodgkin, T. 2002. Genetic diversity and conservation and utilization of plant genetic resources. Plant Cell, Tissue and Organ Culture, 68 (1), 1-19.

Reflinur, Lestari, P. 2015. Determination of gene locus in plant chromosomes with DNA marker (in Indonesian). Jurnal Litbang Pertanian, 34, 177-186.

Schoettle, A.W, Goodrich, B.A., Hipkins, V., Richards, C., Kray, J. 2012. Geographic patterns of genetic variation and population structure in Pinus aristata, Rocky Mountain bristlecone pine. Canadian Journal of Forest Research, 42, 23-37.

Setiawati, T., Mutaqin, A.Z., Irawan, B., An'amillah, A., Iskandar, J. 2017. Species diversity and utilization of bamboo to support life's the community of Karangwangi Village, Cidaun Sub-District of Cianjur, Indonesia. Biodiversitas, 18, 58-64.

Sharma, R.K. et al. 2008. Evaluation of rice and sugarcane SSR markers for phylogenetic and genetic diversity analyses in bamboo. Genom, 51, 91-103.

Sun, Y., Xia, N., Stapleton, C.M.A. 2006. Relationships between Bambusa species (Poaceae, Bambusoideae) revealed by Random Amplified Polymorphic DNA. Biochemical Systematic and Ecology, 34, 417-423.

Szpiech, A.Z., Rosenberg, N.A. 2011. On the Size distribution of private microsatellite alleles. Theoretical Population Biology, 80, 100-113.

Syafaruddin, Nasution, M.A. 2012. Keragaman 17 aksesi plasma nutfah kakao berdasarkan penanda morfologi dan molekuler (in Indonesian). Buletin RISTRI, 3 (2), 177-184.

Triplett, J., Clark, L.G. 2003. Ambiguity and an american bamboo: The Chusquea culeou species complex. Bamboo Science and Culture. Journal of the American Bamboo Society, 17, 21-27.

Turner, K. 2015. Preserving leaf tissue for DNA analysis. http://plantarum.ca/botany/silica/ $20 \mathrm{Ja}-$ nuary 2017.

Vijay, W.N., Uttamkumar, B.S. 2013. Random Amplified Polymorphic DNA based genetic characterization of four important species of bamboo found in Raigad district Maharashtra state India. African Journal of Biotechnology, 12, 4446-4452. 
Widjaja, A.E., Karsono. 2005. Keanekaragaman Bambu di Pulau Sumba (in Indonesian). Biodiversitas, 6 (2), 95-99.

Widjaja, A.E. 2001. Identifikasi jenis-jenis bambu di Jawa (in Indonesian). Puslitbang Biologi. LIPI. Bogor.
Yeasmin, L., Ali, Md. N., Gantait, S. 2015. Bamboo: an overview on its genetic diversity and characterization. 3 Biotech, 5 (1), 1-11.

Zulkarnaen, N.R., Andila, P.S. 2015. Dendrocalamus spp.: bambu raksasa koleksi kebun raya bogor. Prosiding Seminar Nasional Masyarakat Biodiversitas Indonesia, 1 (3), 534-538. 